\title{
Determinants of Vietnam's rice and coffee exports: using stochastic frontier gravity model
}

\author{
Dao Dinh Nguyen \\ The Centre for Agricultural Policy, \\ Institute for Policy and Strategy for Agriculture and Rural Development, \\ Ha Noi, Viet Nam and \\ Crawford School of Public Policy, Australian National University, \\ Canberra, Australia
}

Vietnam's rice and coffee exports

\begin{abstract}
Purpose - The paper aims to estimate the factors affecting Vietnam's export in rice and coffee, the two most important agricultural products, especially in exploring the role of "behind-the-border" constraints.

Design/methodology/approach - The paper applies the stochastic frontier gravity model, which models the aggregate effect of "behind-the-border" factors for Vietnam's export in rice and coffee.

Findings - The paper finds that the impact of "behind-the-border" constraints is statistically significant, suggesting that Vietnam's exports in rice and coffee may be prevented from reaching their export potential by such factors. Moreover, technical efficiency and potential export suggest that Vietnam has a lot of potential to increase its exports in rice and coffee with its major trading partners. The Association of Southeast Asian Nations group continues to be the major market of Vietnamese rice and coffee. Vietnam can also take advantage of the opportunity to export these commodities to the European Union (EU) (not including the UK), and Comprehensive and Progressive Agreement for Trans-Pacific Partnership, especially in coffee to the EU.
\end{abstract}

Research limitations/implications - The study cannot identify specific "behind-the-border" factors due to the limitation of data availability.

\section{JEL Classification - F13, F63, O24}

(C) Dao Dinh Nguyen. Published in Journal of Asian Business and Economic Studies. Published by Emerald Publishing Limited. This article is published under the Creative Commons Attribution (CC BY 4.0) licence. Anyone may reproduce, distribute, translate and create derivative works of this article (for both commercial and non-commercial purposes), subject to full attribution to the original publication and authors. The full terms of this licence may be seen at http://creativecommons.org/licences/by/4.0/ legalcode

The author grateful to Professor Kaliappa Kalirajan and Ms. Trang Pham (Crawford School of Public Policy, Australian National University) for comments and suggestions that help significantly improve my paper. The author also thanks the Editor and the Reviewers for the valuable suggestions provided. Furthermore, I would like to thank Ms. Yangchen Tshering (Crawford School of Public Policy), and Mr. Phuong-Duy Nguyen (Can Tho University, Vietnam) for their English manuscript proofreading support. Any errors in this article are the sole responsibility of the authors.

Funding: No funding.

Corrigendum: It has come to the attention of the publisher that the article Nguyen, D.D. (2020), "Determinants of Vietnam's rice and coffee exports: using stochastic frontier gravity model", published in the Journal of Asian Business and Economic Studies, Vol. ahead-of-print No. ahead-of-print. https://doi. org/10.1108/JABES-05-2020-0054 contained several typographical errors.

In the results section, on page 11 the following sentence was published with incorrect figures: "The export gaps in rice and coffee models are US304.92bn and US\$248.49bn, respectively". The correct figures are: "The export gaps in rice and coffee models are US\$304.92mn and US\$248.49mn, respectively". The error has now been corrected in the online version. The authors sincerely apologise for this.

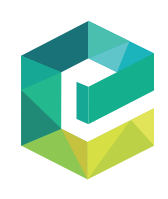

Journal of Asian Business and Economic Studies
Vol. 29 No. 1,2022 pp. $19-34$ Emerald Publishing Limited DOI 10.1108/JABES-05-2020-0054 
JABES

29,1

Originality/value - Many existing studies suggest that export in agricultural products of Vietnam, especially in rice, is significantly affected by natural factors and "explicit beyond-the-border" constraints. They ignore the impact of "behind-the-border" constraints in Vietnam and its trading partners. My study proved the significant impact of such constraints. Therefore, Vietnam needs more policies to remove the "behind-the-border" constraints to promote export in rice and coffee.

Keywords Behind-the-border constraints, Coffee, Rice, The stochastic frontier gravity model Paper type Research paper

\section{Introduction}

In Vietnam, many existing studies have employed the gravity model to estimate determinants of total export and agricultural commodity export, especially its rice export. Research on Association of Southeast Asian Nations (ASEAN) Free Trade Area (AFTA) by Nguyen and Heo (2009) applied the fixed (FE) and random effects (RE) with this model to identify the AFTA's impacts on the total trade volume between Vietnam and Singapore. Moreover, Nguyen (2010) asserted that the incomes of Vietnam and trading partners possess positive signs, while ASEAN membership negatively affects Vietnam's total export by using both static and dynamic gravity models. Regarding the export of agricultural products, Nguyen (2018a) used the ordinary least squares (OLS) and Poisson pseudo-maximum likelihood (PPML) estimator methods and concluded that tariff reduction significantly stimulated exports in manufactured goods but had no clear impact on exports in agricultural commodities to regional comprehensive economic partnership markets.

Furthermore, Vietnam's rice export is of great interest to many researchers. Bui and Chen (2017) used the gravity model to conclude that the gross domestic product (GDP), price, Population (POP) and the exchange rate (ER) had significantly great impacts on the rice export of Vietnam. Besides, the impact of trade agreements on rice export is also estimated. Tran et al. (2019) used OLS and PPML estimator methods and asserted that the impact magnitude of FTAs on export in Vietnamese rice is relatively low, and some of FTAs brought significantly negative effects. Using the gravity model on rice export of Vietnam can be found more in Vu and Doan (2013) and Nguyen (2018b). However, in terms of coffee, there is relatively little research to identify key factors affecting its export.

The literature review suggests that Vietnam's export, especially in agricultural commodities and rice, is significantly affected by natural factors and "explicit beyond-theborder" constraints. Natural factors are determined by the influence of the economic size of exporting and importing countries, or the geographical distance; meanwhile, tariff or exchange rate are some key parts of "explicit beyond-the-border" constraints (Kalirajan and Paudel, 2015). However, these existing studies on Vietnam have ignored the impact of "behind-the-border" constraints in exporting countries and their trading partners such as inefficient institutions. According to Kalirajan and Paudel (2015), some existing behind-theborder factors in developing countries may hinder export activities.

In Vietnam, export in rice and coffee can be negatively affected by "behind-the-border" constraints. First is related to the trading policies of Vietnam, especially in the rice sector. Nguyen et al. (2017) asserted that although participating in the World Trade Organization (WTO), Vietnam's rice has not been completely reformed to comply with market rules due to tension between socialist policy legacy and trade liberalization goals. Besides, Vietnamese political institutions have created favourable conditions for political and economic elites in a way they can apply policies and trading actions that are expected to benefit them such as trading restrictions (Fulton and Reynolds, 2015). These actions may reduce the export potential of Vietnamese rice.

Furthermore, the second is the traditional technique of rice and coffee production, highly depending on fertilizer and pesticides. This leads to the degradation of soil and water ecosystems, negatively affecting the productivity and quality of these products (Nguyen, 
2017). Moreover, climate change such as drought and saline intrusion in the Central Highlands and Mekong Delta in recent years have reduced production areas and crop yields (UNDP, 2016).

Therefore, it is very important to measure the influence of "behind-the-border" factors on export (Kalirajan and Paudel, 2015), especially in Vietnam. However, the measurement is difficult to implement when researchers have limited knowledge or data availability on these constraints (Kalirajan and Paudel, 2015). To overcome this issue, Kalirajan (2008) proposed the application of a stochastic frontier gravity approach (SFGA). Accordingly, the aggregate effect of these constraints on export can be modelled within the framework of SFGA (Kalirajan and Paudel, 2015).

This study aims to estimate the determinants of Vietnam's exports in rice and coffee. The study will focus on the 19-year period from 2000-2018, with 40 main trading partners of rice and 35 of coffee, based on the total export value in this period. Besides FE and PPML, the paper will use SFGA, which models the effect of "behind-the-border" constraints.

The study proves the highly significant effect of "behind-the-border constraints" on export in rice and coffee, leading to the chosen SFGA method. Accordingly, there is a significantly positive relationship between Vietnam's GDP and its exports in these commodities. While GDPs of trading partners positively affect coffee export, we find significantly negative impacts on rice export. Regarding the impact of the ASEAN group, both models provide significantly positive results. Besides, ASEAN is expected to be the main market of Vietnam in these goods due to the low technical efficiency and the high potential export. Although SFGA finds the insignificant impact of EU for both models and a significant effect of Comprehensive and Progressive Agreement for Trans-Pacific Partnership (CPTPP) on coffee export, the technical efficiency and potential export still suggest that they will be targeted markets of Vietnam when new trade agreements (EU, CPTPP) comes into effect.

The rest of the papers will be structured as follows. The next section describes data and methodology before discussing the empirical findings. Conclusions are presented in the last section.

\section{Methodology and data \\ Methodology}

In terms of rice and coffee commodities, Vietnam's export growth has rapidly increased since becoming an official member of the WTO in 2007. The rice's export value of Vietnam in 2018 was US\$2.62bn, targeting China, Philippines, Indonesia and Malaysia. Meanwhile, the figure for Vietnamese coffee is US\$2.89bn in 2018 with the main markets, including Germany, the USA and Italy (UN Comtrade, 2020). Economic integration has expanded many international markets to create motivation for the export growth of these products. Therefore, for developing export strategies, the key questions are what the potential markets are and whether they have a lot of room for exploitation. The gravity model is a suitable theoretical model to answer these questions. It is also the most popular quantitative method to estimate trade flows in a multi-country environment.

In this paper, the gravity model for Vietnam's export in rice and coffee is as follows:

$$
\begin{aligned}
\operatorname{lnEX} \mathrm{X}_{i t}= & b_{0}+b_{1} \operatorname{lnGDP}_{V N t}+b_{2} \operatorname{lnGDP}_{i t}+b_{3} \operatorname{lnPOP}_{i t}+b_{4} \operatorname{lnDis}_{V N i}+b_{5} \text { contig }_{V N i t} \\
& +b_{6} C_{t}+\varepsilon_{t}
\end{aligned}
$$

The acronyms of the variables are explained in Table 1.

Some argued that using OLS on the intuitive gravity model can lead to biased and inconsistent estimators (Kalirajan, 2008). First, the biased estimators are caused by omitted
Vietnam's rice and coffee exports

\section{(1)}




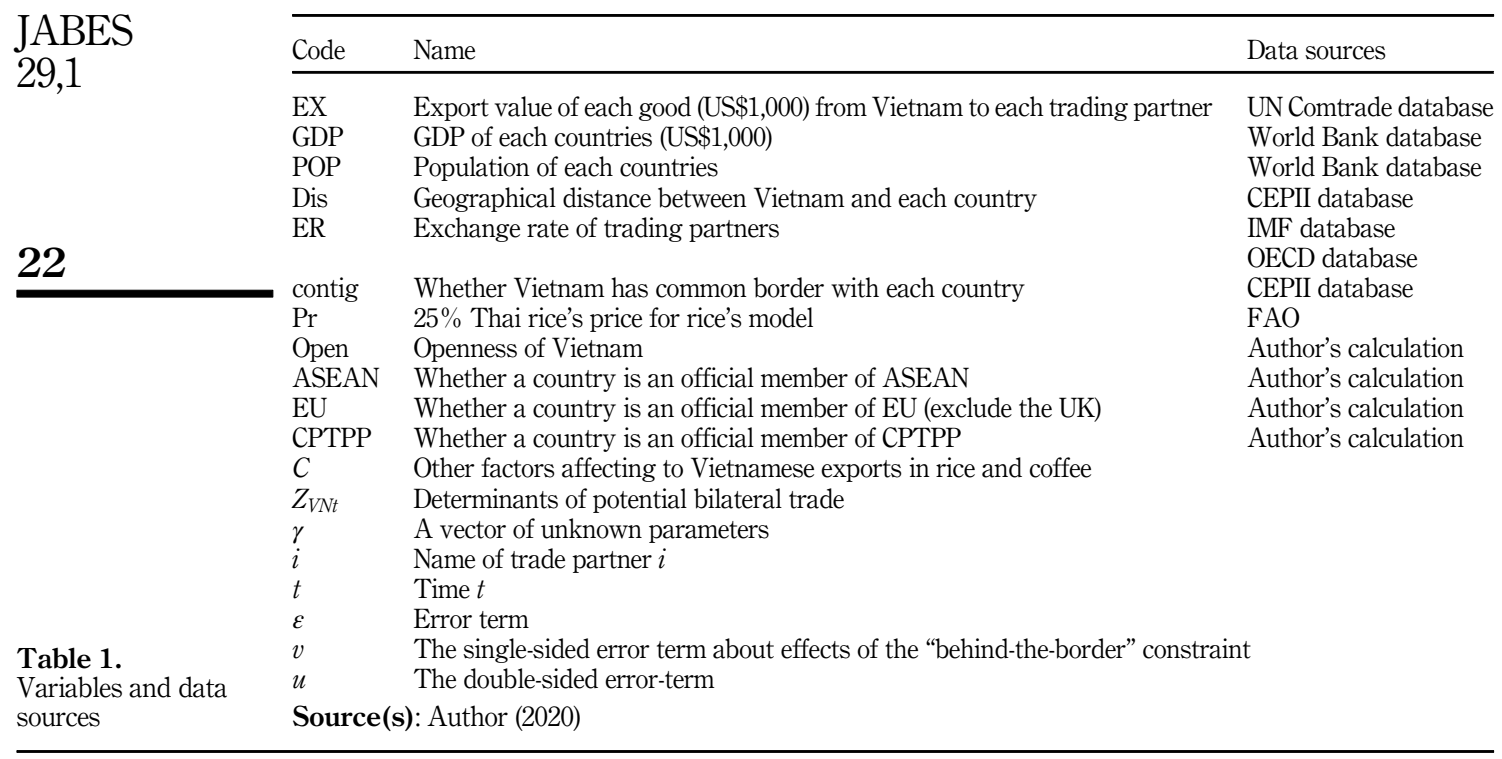

variables, which are highly correlated with one of the independent variables (Kalirajan, 2008) in equation (1). The second reason of the biased estimators is due to the presence of heteroskedasticity in the log-linear function (Silva and Tenreyno, 2006). Besides, sample selection bias can occur when the econometric models drop zero values of the dependent variable during the transformation into logarithmic form (Heckman, 1979 cited in Haq et al., 2013).

Nasrullah et al. (2020) argued that using panel data analysis like FE is appropriate to control the possible endogeneity error caused by unobserved heterogeneity. Besides, Silva and Tenreyno (2006) found that PPML may deal with the selection bias from zero value of trade and provide the unbiased and consistent estimators in the presence of heteroskedasticity. Moreover, PPML with panel data can cope with the bias obtained from national heterogeneity (Westerlund and Wilhelmsson, 2011).

However, these methods ignore the effect of the "behind-the-border" constraints in the exporting countries, leading to incorrect estimated coefficients. To address this issue, Kalirajan (2008) proposed the SFGA method by modelling the combined impact of all "behind-the-border" factors on export. The SFGA equation is as follows:

$$
\ln \mathrm{EX}_{V N i t}=f\left(\ln Z_{V N i t} ; \ln \gamma\right)+\left(v_{t}-u_{t}\right)
$$

Equation (1) will become:

$$
\begin{aligned}
\ln \mathrm{EX}_{i t}= & b_{0}+b_{1} \operatorname{lnGDP}_{V N t}+b_{2} \operatorname{lnGDP}_{i t}+b_{3} \operatorname{lnPOP}_{i t}+b_{4} \operatorname{lnDis}_{V N i}+b_{5} \text { contig }_{V N i t} \\
& +b_{6} C_{t}+\left(v_{t}-u_{t}\right)
\end{aligned}
$$

According to Kalirajan (2007), in addition to the natural factors and "explicit beyond-theborder" constraints, the "behind-the-border" factors may affect the gap in their actual and potential exports. This gap is implied in the single-sided error term, $u_{t}$. If $u_{t}$ goes to 1 , such constraints will be a barrier to preventing actual exports from reaching their full potential. Therefore, determining the impacts of such constraints is important to 
minimize export constraints. Exporting countries can reform their policies or create necessarily important criteria for their trade negotiations to be able to reach their maximum potential in exports. Besides, other variables such as "behind-the-border" factors of trading partners and statistical error terms are evaluated in the double-sided error term $v_{t}$. The modelling regression assumes that the $v_{t}$ term randomly distributes following a normal distribution.

There are advantages of using SFGA for a gravity model of trade (Kalirajan, 2007). First, equation (2) is not affected by the estimation efficiency loss. Second, the economic distance bias term, which leads to the heteroskedasticity issue, will be corrected by isolating it from the error term. Finally, Kalirajan (2007) asserted that SFGA carries strong theoretical implications in trade policy.

\section{Data}

The study uses the UN Comtrade database to collect the export data of Vietnam from 2000 2018. To identify research products, I primarily use the four-digit harmonized system (HS) code. Specifically, the HS code for rice and "roasted and not roasted" coffee are HS 1006 and HS 0901, respectively. The selected trading partners are listed in Table 9.

Beside some main variables (GDP, POP, Dis), equation (1) will explore other variables $(C)$ that affect Vietnam's exports in rice and coffee. These include exchange rates of trading partners, common border, 25\% Thai rice's price (for rice model), trade openness of Vietnam and dummy variables that reflect whether a country is an official member of ASEAN, European Union (EU) (exclude the UK) and CPTPP. The paper wants to compare the difference in trade among ASEAN, EU, CPTPP countries with others. Besides, the trade openness of Vietnam is determined by the formula: Open = Total Trade/GDP. The descriptive statistics of all variables used in this study will be presented in Table 2.

\begin{tabular}{|c|c|c|c|c|c|c|}
\hline Model & Variable & No. of obs. & Mean & $\mathrm{SD}$ & Min & Max \\
\hline \multirow[t]{11}{*}{ Rice model } & $\operatorname{lnEX}$ & 681 & 8.988 & 2.211 & -0.216 & 13.979 \\
\hline & lnGDPVN & 760 & 18.364 & 0.691 & 17.255 & 19.318 \\
\hline & lnGDPi & 760 & 18.264 & 2.252 & 12.994 & 23.746 \\
\hline & $\operatorname{lnPOPi}$ & 760 & 16.841 & 1.636 & 12.716 & 21.055 \\
\hline & Lndist & 760 & 8.723 & 0.705 & 6.766 & 9.657 \\
\hline & $\operatorname{lnER}$ & 760 & 3.563 & 2.851 & -0.607 & 10.618 \\
\hline & lnPriceTh & 760 & 5.788 & 0.426 & 5.028 & 6.402 \\
\hline & lnOpen & 760 & 7.228 & 0.205 & 6.863 & 7.581 \\
\hline & ASEAN & 760 & 0.125 & 0.331 & 0.000 & 1.000 \\
\hline & $\mathrm{EU}$ & 760 & 0.025 & 0.156 & 0.000 & 1.000 \\
\hline & СРТPР & 760 & 0.125 & 0.331 & 0.000 & 1.000 \\
\hline \multirow[t]{11}{*}{ Coffee model } & $\operatorname{lnEX}$ & 659 & 9.678 & 1.742 & 3.474 & 13.127 \\
\hline & $\operatorname{lnGDPVN}$ & 665 & 18.364 & 0.691 & 17.255 & 19.318 \\
\hline & $\operatorname{lnGDPi}$ & 665 & 19.949 & 1.522 & 16.392 & 23.746 \\
\hline & $\ln \mathrm{POPi}$ & 665 & 17.487 & 1.410 & 14.503 & 21.055 \\
\hline & Lndist & 665 & 8.779 & 0.672 & 6.898 & 9.780 \\
\hline & $\operatorname{lnER}$ & 665 & 1.594 & 2.234 & -0.694 & 9.564 \\
\hline & lnPriceTh & 665 & 5.788 & 0.426 & 5.028 & 6.402 \\
\hline & lnOpen & 665 & 7.228 & 0.205 & 6.863 & 7.581 \\
\hline & ASEAN & 665 & 0.143 & 0.350 & 0.000 & 1.000 \\
\hline & $\mathrm{EU}$ & 665 & 0.343 & 0.475 & 0.000 & 1.000 \\
\hline & СРТРP & 665 & 0.171 & 0.377 & 0.000 & 1.000 \\
\hline
\end{tabular}

Source(s): Author's calculation (2020)
Vietnam's rice and coffee exports 位 


\section{JABES 29,1}

\section{4}

\section{Results}

Unit-roots test

The paper used Levin-Lin-Chu (LLC) test to test for stationary in panel data. The rejected null hypothesis provides evidence for stationary panels. If the panel is not stationary, the regression estimations may be spurious. Table 3 provides the results of the LLC test and see that all tests are statistically significant at 5 or $10 \%$, implying that the panel datasets are stationary.

\section{Model specification for panel analysis}

In this part, some tests will be conducted to choose which of three panel analysis methods (pooled OLS, FE, RE) is appropriate for each model. F-tests result rejects the null hypothesis of poolability, so FE is more appropriate than pooled OLS. The Breusch-Pagan Lagrange multiplier test is statistically significant, leading to the chosen RE method rather than pooled OLS. Finally, the Hausman test rejects the null hypothesis, so the FE method is preferred in comparison with RE because of the inconsistent estimated coefficients of the latter. The results of these tests are presented in Table 4. Accordingly, FE will be preferred for both models.

Further, the paper conducted the modified Wald test to check for heteroskedasticity. Table 5 shows that the results are statistically significant, leading to the presence of heteroskedasticity when using $\mathrm{FE}$. Therefore, $\mathrm{FE}$ will be the obtained robust standard error to deal with this issue.

\section{Sensitivity check analysis for stochastic frontier gravity approach method}

Table 6 presents the results for sensitivity check analysis by using SFGA. Accordingly, the values of gamma in both models are statistically significant (through $t$-test of ilgtgamma, the estimate of gamma). This implies the significant impacts of "behind-the-border" constraints in Vietnam and its trading partners. The values of gamma in rice and coffee models are very high at 73.4 and $79.8 \%$, respectively. The larger gamma coefficients imply the presence of the "behind-the-border" factors, and they are responsible for a big proportion of mean total variations in each model. Therefore, the high significance of gamma indicates that the SFGA method is more appropriate to estimate export's determinants of rice and coffee. Further, it suggests that Vietnam's exports in these goods may be prevented from reaching their export potential by these constraints.

The Wald test statistics are also significant in both models at the $1 \%$ level, implying that the structures of the SFGA method with selected explanatory variables explained the

\begin{tabular}{|c|c|c|c|c|c|c|c|}
\hline & $\operatorname{lnEX}$ & $\operatorname{lnGDP} i$ & $\operatorname{lnGDPVN}$ & $\ln \mathrm{POP} i$ & $\operatorname{lnER}$ & lnOpen & lnPriceTh \\
\hline \multicolumn{8}{|l|}{ Rice's model } \\
\hline Unadjusted $t$ & -10.528 & -9.138 & -11.889 & -17.600 & -7.321 & -7.148 & -13.408 \\
\hline Adjusted $t^{*}$ & -2.646 & -6.861 & -11.134 & -18.942 & -1.618 & -4.689 & -7.939 \\
\hline$p_{\text {_vvalue }}$ & 0.004 & 0.000 & 0.000 & 0.000 & 0.053 & 0.000 & 0.000 \\
\hline Conclusion & Stationary & Stationary & Stationary & Stationary & Stationary & Stationary & Stationary \\
\hline \multicolumn{8}{|l|}{ Coffee's model } \\
\hline Unadjusted $t$ & -13.2227 & -11.1281 & -11.1208 & -2.7443 & -10.7195 & -6.6859 & \\
\hline Adjusted $t^{*}$ & -9.4787 & -8.5564 & -10.415 & -1.9038 & -4.0172 & -4.3865 & \\
\hline p_value & 0.0000 & 0.0000 & 0.0000 & 0.0285 & 0.0000 & 0.0000 & \\
\hline Conclusion & Stationary & Stationary & Stationary & Stationary & Stationary & Stationary & \\
\hline \multicolumn{8}{|c|}{ Source(s): Author's estimation (2020) } \\
\hline
\end{tabular}

\footnotetext{
Source(s): Author's estimation (2020)
}

Table 3.

Test for unit roots 
JABES

29,1

26

variations in rice and coffee exports well. Moreover, $m u$ is statistically significant, resulting in its truncated normal distribution in each model. The values of $e t a$ are negative, meaning that the degree of rice and coffee exports inefficiencies increase over time. These hypothesises further confirm the preference of the SFGA method in both models.

\section{Export's determinants of rice}

Table 7 presents the impact of factors on Vietnam's rice export through different approaches of a gravity model. The dependent variable is the logarithmic value of rice export in the basic gravity models with FE, and SFGA, except for PPML where this variable is determined in its value.

Regarding the influence of importing countries, FE provides the insignificantly positive impacts of their GDP on rice export, while the significantly negative effects were found in PPML and SFGA. Besides, all models find the same impact signs of their POP on rice exports; however, PPML and SFGA provide statistically significant values. The magnitudes in PPML and SFGA are also smaller than those in FE. Moreover, the only PPML shows that the ER of importing nations has a negative and significant effect on export in rice of Vietnam. Meanwhile, SFGA shows its impact is positive and not statistically significant.

The impact of Vietnam's economy on rice exports is reflected in GDP and openness. FE methods show the insignificant impact of Vietnam's GDP on rice export. Meanwhile, the estimated coefficients of Vietnam's GDP on PPML and SFGA methods are positive and statistically significant, tested at 10 and $1 \%$ levels, respectively. It means that an increase in the GDP of Vietnam leads to a higher rice export, holding others constant. Regarding the impact of openness, all methods show negative effects. Only FE provides statistically significant coefficients of lnOpen.

Table 5.

Test for heteroskedasticity in FE method

\begin{tabular}{lll}
\hline & & Modified Wald test \\
\hline Rice's model & $\ln \mathrm{EX}$ & Chi square $=12,382.69 p \_$value $=0.0000$ \\
& $\ln (\mathrm{EX}+1)$ & Chi square $=9,747.85 p \_$value $=0.0000$ \\
Coffee's model & $\ln \mathrm{CX}$ & Chi square $=6,912.37 p \_$value $=0.0000$ \\
& $\ln (\mathrm{EX}+1)$ &
\end{tabular}

Source(s): Author's estimation (2020)

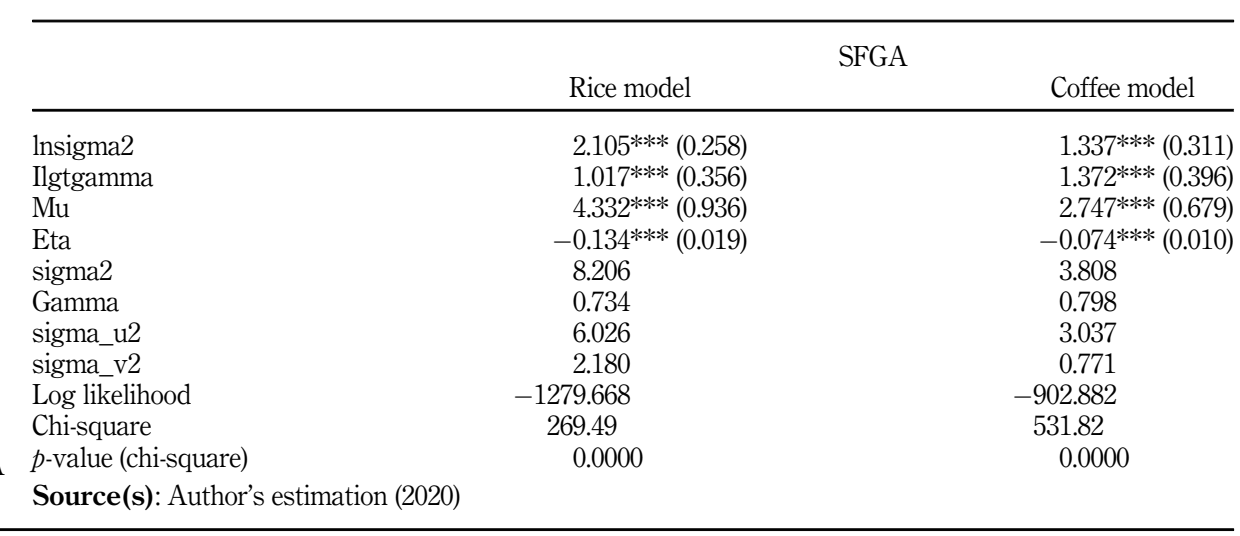

Table 6.

Sensitivity check analysis for the SFGA method 


\begin{tabular}{|c|c|c|c|c|c|}
\hline $\begin{array}{l}\text { Dependent } \\
\text { variable }\end{array}$ & $\begin{array}{l}\text { FE with robust } \\
\ln (\mathrm{EX})\end{array}$ & $\begin{array}{l}\text { FE with robust } \\
\ln (\mathrm{EX}+1)\end{array}$ & $\begin{array}{l}\text { PPML with robust } \\
\text { EX }\end{array}$ & SFGA $\ln (\mathrm{EX})$ & and coffee \\
\hline $\operatorname{lnGDP} i$ & $0.699(0.672)$ & $0.593(0.701)$ & $-0.262 * * * *(0.051)$ & $-0.342 * * * *(0.076)$ & \\
\hline $\ln \mathrm{POP} i$ & 1.124 (2.102) & 2.894 (2.011) & $0.491 * * *(0.065)$ & $0.570 * * *(0.103)$ & \\
\hline $\operatorname{lnGDPVN}$ & $-0.079(0.808)$ & $0.038(1.014)$ & $0.763 *(0.415)$ & $2.545 * * *(0.416)$ & \\
\hline $\operatorname{lnER}$ & $-0.043(0.508)$ & $-1.194(0.827)$ & $-0.120 * * *(0.031)$ & $0.035(0.043)$ & \\
\hline lnPriceTh & $1.104 * *(0.536)$ & $2.053 * * *(0.708)$ & $0.998 * * *(0.331)$ & $-0.226(0.333)$ & \\
\hline lnOpen & $-1.683^{*}(0.859)$ & $-2.217^{*}(1.303)$ & $-0.699(1.077)$ & $-0.165(0.838)$ & \\
\hline lndist & & & $-0.108(0.140)$ & $0.274(0.176)$ & \\
\hline contig & & & $1.722 * * *(0.301)$ & $-0.486(0.573)$ & \\
\hline ASEÅN & & & $2.490 * * *(0.223)$ & $2.826^{* * * *}(0.381)$ & \\
\hline $\mathrm{EU}$ & & & $-1.733 * * *(0.350)$ & $-0.130(0.609)$ & \\
\hline СРТРP & & & $-0.683 * * * *(0.183)$ & $0.170(0.371)$ & \\
\hline _cons & $-15.519(28.954)$ & $-43.823(28.104)$ & $-7.325^{* *}(3.177)$ & $-39.692^{* * * *}(6.231)$ & \\
\hline $\bar{R}^{2}$ & 0.13 & 0.16 & 0.58 & & \\
\hline$N$ & 681 & 760 & 760 & 681 & \\
\hline \multicolumn{5}{|c|}{$\begin{array}{l}\text { Note(s): } * p<0.1 ; * * p<0.05 ; * * * p<0.01 \\
\text { Source(s): Author's estimation }(2020)\end{array}$} & $\begin{array}{l}\text { The estimated } r \\
\text { for rice's } 1\end{array}$ \\
\hline
\end{tabular}

The paper wants to explore the impact of Thai rice price on Vietnam's rice exports. I argue that when the price of $25 \%$ Thai rice rises, it will increase the competitiveness of Vietnamese rice in the global market. As a result, rice exports in Vietnam will increase. This positive effect was found in all methods, except SFGA. The estimated coefficients of $\ln P r i c e T h$, using FE and PPML, are all statistically significant, tested at 5 or $10 \%$ levels; meanwhile, its insignificance is found in SFGA.

In addition, FE cannot measure the impact of geographical distance, common border and some market groups such as ASEAN, the EU and CPTPP because these variables do not change over time. However, PPML and SFGA can estimate the impact of these invariant variables on rice export. Both methods present that the effect of geographical distance is insignificant. Besides, PPML indicated a positive and statistically significant impact of contig in Vietnamese rice exports, while it was found to be negative and insignificant in the SFGA model.

Both PPML and SFGA show significantly positive coefficients of ASEAN. It means that the value of Vietnamese rice export to ASEAN countries is significantly higher than in other markets. Meanwhile, the estimated coefficients of the EU are negative and only statistically significant in PPML. The result from PPML also suggests that rice export of Vietnam to CPTPP countries is significantly lower than others. Meanwhile, SFGA shows the opposite when the impact of CPTPP is insignificant.

\section{Export's determinants of coffee}

The estimated results for the coffee model are presented in Table 8. The result shows positive and statistically significant impacts of the partner's GDP on coffee export in all methods. Besides, the impacts of POP of importing countries are not significant in PPML and FE methods. The estimated coefficient of $\mathrm{POPi}$ from SFGA is negative and statistically significant. So, SFGA tells that the bigger the population of importing countries, the lower their demand on Vietnamese coffee. Regarding the exchange rate of importing countries, only $\mathrm{FE}$ produces a positive and statistically significant impact on coffee export. Meanwhile, its insignificant impacts are found in SFGA and PPML.

For Vietnam's GDP, all methods produce significantly positive effects. This suggests that the productive capacity of Vietnam plays a vital role in promoting coffee export. Besides, the 


\begin{tabular}{|c|c|c|c|c|c|}
\hline $\begin{array}{l}\text { JABES } \\
29,1\end{array}$ & $\begin{array}{l}\text { Dependent } \\
\text { variable }\end{array}$ & $\begin{array}{l}\text { FE with robust } \\
\ln (\mathrm{EX})\end{array}$ & $\begin{array}{l}\text { FE with robust } \\
\ln (\mathrm{EX}+1)\end{array}$ & $\begin{array}{l}\text { PPML with robust } \\
\text { EX } \\
\end{array}$ & SFGA $\ln (\mathrm{EX})$ \\
\hline \multirow[b]{5}{*}{28} & $\ln \mathrm{GDP} i$ & $1.364^{* * * *}(0.459)$ & $1.443 * * *(0.501)$ & $0.694 * * * *(0.038)$ & $1.113^{* * * *}(0.079)$ \\
\hline & $\ln \mathrm{POP} i$ & $-1.973(3.525)$ & -1.809 (3.771) & $-0.062(0.043)$ & $-0.787 * * *(0.110)$ \\
\hline & $\operatorname{lnGDPVN}$ & $1.022^{* * *}(0.242)$ & $1.120 * * *(0.294)$ & $0.810 * * * *(0.140)$ & $1.546 * * *(0.159)$ \\
\hline & $\operatorname{lnER}$ & $1.407 * *(0.679)$ & $1.511^{* *}(0.743)$ & $0.005(0.020)$ & $-0.009(0.053)$ \\
\hline & lnOpen & $-0.953 * *(0.364)$ & $-1.067 * *(0.488)$ & $-0.358(0.456)$ & $0.612(0.497)$ \\
\hline \multirow{8}{*}{$\begin{array}{l}\text { Table } 8 \text {. } \\
\text { The estimated results } \\
\text { for coffee's model }\end{array}$} & Indist & & & $-0.003(0.090)$ & $\begin{array}{r}0.259(0.219) \\
1846 * * *(0656)\end{array}$ \\
\hline & $\begin{array}{l}\text { contig } \\
\text { ASEAN }\end{array}$ & & & $\begin{array}{r}-1.451 \text { *** (0.188) } \\
0.432 * * *(0.129)\end{array}$ & $\begin{array}{l}1.846^{* * * * *}(0.656) \\
1.434^{* * * *}(0.409)\end{array}$ \\
\hline & $\begin{array}{l}\text { ASEAN } \\
\text { EU }\end{array}$ & & & $\begin{array}{l}0.432^{* * *}(0.129) \\
0.643 * * *(0.094)\end{array}$ & $\begin{array}{r}1.434 . \\
0.131(0.229)\end{array}$ \\
\hline & СТPP & & & $-0.415^{* * * *}(0.091)$ & $-0.700^{\circ * * *}(0.269)$ \\
\hline & cons & $2.822(54.502)$ & $-2.817(58.428)$ & $-15.098 * * *(1.693)$ & $-32.392 * * * *(3.882)$ \\
\hline & $R^{2}$ & 0.54 & 0.47 & 0.71 & \\
\hline & $N$ & 659 & 665 & 665 & 659 \\
\hline & \multicolumn{5}{|c|}{$\begin{array}{l}\text { Note(s): } * p<0.1 ; * * p<0.05 ; * * * p<0.01 \\
\text { Source(s): Author's estimation }(2020)\end{array}$} \\
\hline
\end{tabular}

impact magnitude estimated by SFGA is the highest. Regarding the impact of openness, FE produces significantly negative coefficients of $\ln O p e n$; meanwhile, trade openness is insignificant in PPML and SFGA.

The geographical distance is expected to reduce coffee export in PPML, while SFGA suggests its positive impact. However, the estimated coefficients of lndist in these models are not significant. Countries sharing a common border with Vietnam have a significantly lower probability of importing Vietnamese coffee, estimated by PPML, while SFGA shows its significantly positive influence.

ASEAN is expected to be a potential market for Vietnamese coffee. The estimated values of ASEAN variables in both PPML and SFGA are positive and statistically significant, leading significantly higher values than other markets. Besides, PPML predicts that the EU will be a target market of Vietnamese coffee wherein its estimated coefficient is positive and statistically significant. SFGA also produces a positive coefficient of the EU, but it is insignificant. On the contrary, the estimated impact of CPTPP is significantly negative. It means that the ability to export Vietnamese coffee to CPTPP countries is lower than in other markets.

\section{Which method is appropriate?}

Using FE with the basic gravity model faces some problems. First, FE will lose the information of time-invariant variables like geography distance, common border or country groups. Besides, the model will delimit the zero trade, leading to selection bias in the case of using FE for $\ln (E X)$. Meanwhile, PPML can overcome selection bias created by zero trade and the presence of heteroskedasticity. This method also covers the impact of time-invariant variables that cannot be obtained by FE. Besides, the goodness of fit of PPML (through $R^{2}$ ) is higher than FE, leading to higher fitness of the models. Therefore, PPML is more appropriate than FE.

However, both FE and PPML ignore the effects of "behind-the-border" constraints of exporting countries, leading to unbiased estimators. As discussed above, the study concluded strongly significant effects of such constraints in both models by using SFGA. Therefore, the SFGA method is preferred to estimate export's determinants of Vietnamese rice and coffee. The following part will focus on the estimated results of SFGA on both models. 
The coffee model shows higher the income (GDP) of trading partners, higher export value. This has been found in other studies on Vietnamese export such as Nguyen and Heo (2009) or Tran (2017). However, the rice model shows significantly negative results by SFGA. It is in line with Nguyen (2018a, b). This can be explained by the low elasticity of rice demand. Besides, because of Engel's law, as income increases, the consumption of basic goods like rice will decline. In addition, the higher the population, the greater the demand for their goods, attracting export flows of exporting countries (Bui and Chen, 2017). This has also been verified in the rice model. Meanwhile, the coffee model concluded the significantly negative impact of the trading partner's population on export. As for the exchange rate of importing countries, both rice and coffee models conclude the insignificant impacts on exports.

On the impact of the domestic side, both models conclude significantly positive impacts of GDP on exports. Accordingly, if Vietnam's GDP increases by $1 \%$, its rice and coffee export of Vietnam will be increased by 2.545 and $1.546 \%$, respectively, holding others constant. As Vietnam's key agricultural export goods, the higher GDP will stimulate production development, results in a higher supply of goods for export purposes. Besides, Wei (2016) concludes that the openness of trade stimulates technology transmission, efficient resource allocation and knowledge spillovers. Therefore, higher trade openness of exporting countries can promote domestic production for trade purposes. In this study, however, SFGA in rice and coffee models show that the impact of trade openness of Vietnam is insignificant on export.

The geographical distance between exporting countries and each partner also affect export value due to transportation costs and risks. The close distance will reduce transportation costs, leading to the promotion of export activities (Bui and Chen, 2017). However, using SFGA in both models shows the insignificant positive impact of dist. Besides, both models also give the insignificant negative results about the impact of the common border (contig) on export. These results suggest that technological innovation and development in Vietnam can reduce transportation costs and risks, leading to blurring the role of geographical distance on export.

Regarding the impact of country groups, the study shows that ASEAN members had significantly higher import demand for Vietnam's rice and coffee. The impact of the EU group is positive on the coffee model; meanwhile, the negative effect of EU members is found in the rice model. Compared to other countries, the coffee export of Vietnam to the EU group is higher, and its rice export to this market is lower, although they are not significant. Besides, in the coffee model, CPTPP countries showed a negative and statistically significant impact. Meanwhile, the rice model pointed out an insignificantly positive effect. In conclusion, this partly confirms the important role of ASEAN with the export in both commodities and that of the EU with coffee export.

\section{Export performance of rice and coffee}

In this section, the study uses SFGA to estimate the average technical efficiency and potential export in Vietnam's rice and coffee in the research period. The results are presented in Table 9. The technical efficiency presents the performance of Vietnam's export in rice and coffee with any trading partner. Our estimated results show that in both models, none of the countries reaches the optimal level, 100\% technical efficiency. Besides, both models show that the potential export is higher than the actual export in all trading partners, excluding China and Hong Kong (rice model) and Algeria (coffee model). These suggest that Vietnam still has a lot of potentials to increase its rice and coffee exports in all trading countries, excluding China, Hong Kong (rice) and Algeria (coffee).

For the rice export, ASEAN members like the Philippines, Indonesia, Malaysia and Singapore witness the highest absolute gap between actual export and potential export but low levels of technical efficiency. Therefore, ASEAN continues to be major markets for Vietnam's rice.

\section{Vietnam's rice and coffee exports}


JABES

29,1

30

Table 9.

The average technical efficiency and potential exports of Vietnam towards its main markets during 2000-2018 t.

ฉ্

ก

ฟั่

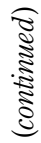

舟饮

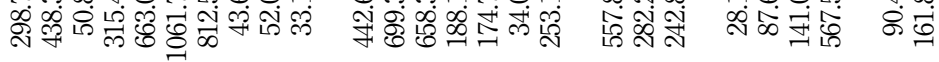

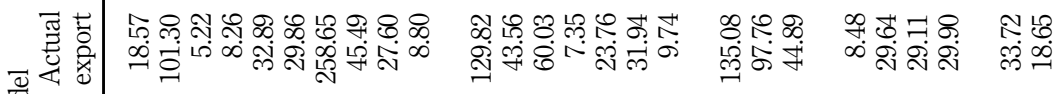
:

迅

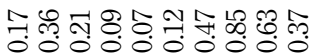

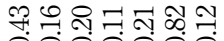

กิ

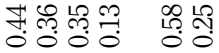

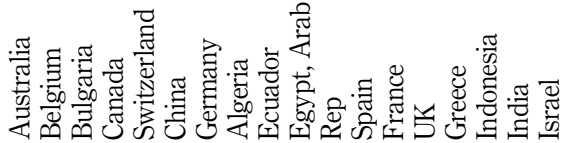

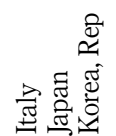

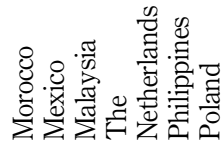

¿্ర

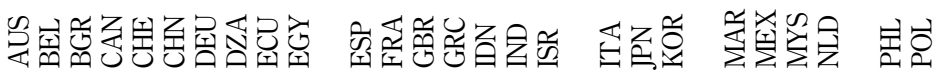

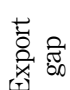

ช ஜ ஸิ่

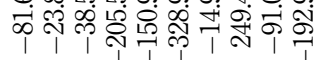

ๆ

$\sim$

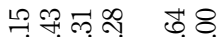

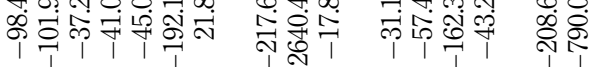

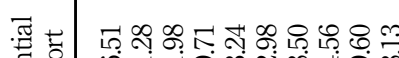

沊

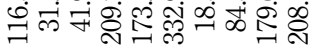

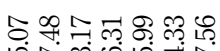

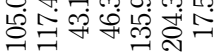

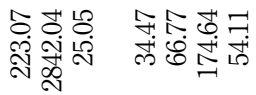

웅

จิ

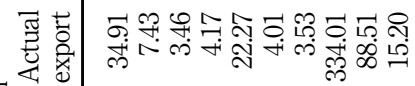

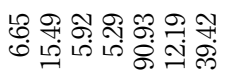

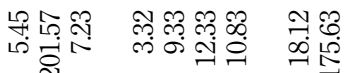

छ্ّ

递

运这

卢范

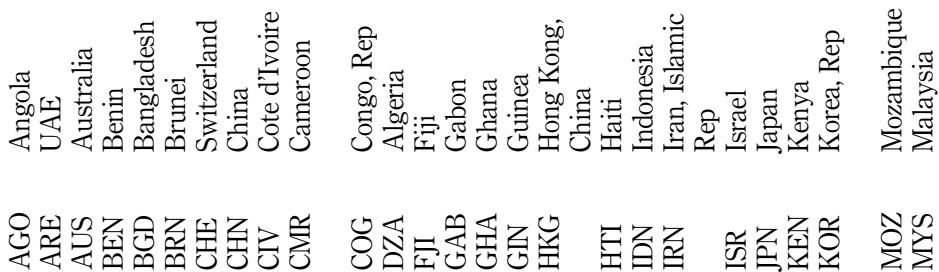




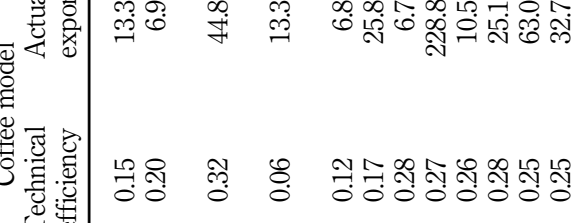

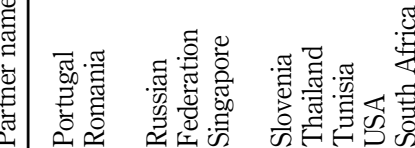

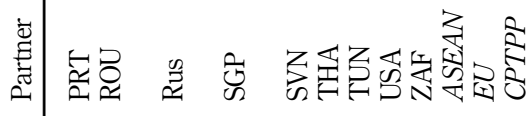

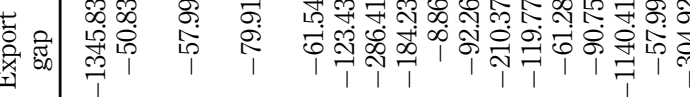

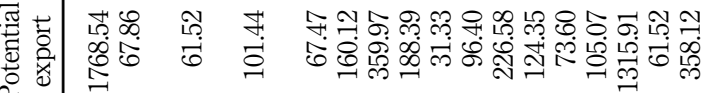

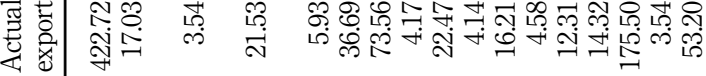

는

|

Table 9. 
JABES

29,1

32

For the coffee model, the EU will be the most important market of Vietnam. The technical efficiencies of each member of the EU group are relatively low (the average value of the EU is 0.25). Besides, their actual exports are far away from reaching their potential exports. Therefore, when the EU-Vietnam Free Trade Agreement (EVFTA), which was signed in June 2019, comes into effect, the export in Vietnamese coffee is expected to be increasing significantly.

Furthermore, Table 9 represents that the CPTPP market has a lot of potential for Vietnam. The values of technical efficiency in rice and coffee models are 29 and $24.8 \%$, respectively. The export gaps in rice and coffee models are US304.92mn and US $\$ 248.49 \mathrm{mn}$, respectively. Therefore, increasing trade relations with CPTPP, which comes to effect in Vietnam since January 2019, may stimulate Vietnam's export of rice and coffee in the future.

\section{Conclusion}

This study uses FE, PPML to overcome the selection bias from zero trade and the presence of heteroskedasticity. However, these methods ignore the impact of "behind-the-border" constraints that are proven with statistical significance in SFGA. Therefore, the paper argues that SFGA is appropriate to measure the main determinants of export in rice and coffee, two key agricultural commodities of Vietnam. The panel dataset is drawn from 2000-2018. The paper shows that trading partner's GDP has a significantly positive impact on coffee export while a significantly negative effect on rice export. The role of Vietnam's GDP become significantly important in both models.

Moreover, the impacts of ASEAN are significantly positive in both models. While the impact of CPTPP is insignificant in the rice model, its significantly negative effect is found in the coffee model. There are insignificant impacts of the EU in both models. Besides, the paper also suggests that technological innovation and development in Vietnam can reduce transportation costs and risks, leading to blurring the role of geographical distance on export.

In addition, the technical efficiency, estimated by SFGA, shows that Vietnam has a lot of potentials to increase its exports in rice and coffee with major trading partners. ASEAN will continue to be the main market of Vietnam in these two commodities. New trade agreements such as the EU and CPTPP is expected to increase exports of these two commodities of Vietnam, especially coffee exports to the EU market.

Conclusion, SFGA indicates that Vietnam needs more policies to remove the "behind-theborder" constraints to promote export in rice and coffee. This paper, however, cannot identify specific "behind-the-border" factors due to the limitation of data availability.

\section{References}

Bui, T.H.H. and Chen, Q. (2017), "An analysis of factors influencing rice export in Vietnam based on gravity model", Journal of the Knowledge Economy, Vol. 8 No. 3, pp. 830-844, doi: 10.1007/ s13132-015-0279-y.

Fulton, M.E. and Reynolds, T. (2015), "The political economy of food price volatility: the case of Vietnam and rice", American Journal of Agricultural Economics, Vol. 97 No. 4, pp. 1206-1226, doi: 10.1093/ajae/aav019.

Haq, Z.U., Meilke, K. and Cranfield, J. (2013), "Selection bias in a gravity model of agrifood trade", European Review of Agricultural Economics, Vol. 40 No. 2, pp. 331-360, doi: 10.1093/erae/jbs028.

Kalirajan, K. (2007), "Regional cooperation and bilateral trade flows: an empirical measurement of resistance", International Trade Journal, Vol. 21 No. 2, pp. 85-107, doi: 10.1080/ 08853900701266555.

Kalirajan, K. (2008), "Gravity model specification and estimation: revisited", Applied Economics Letters, Vol. 15 No. 13, pp. 1037-1039, doi: 10.1080/13504850600993499. 
Kalirajan, K. and Paudel, R. (2015), "India's trade deficit with China: will free trade agreement (FTA) work for India?”, Global Economy Journal, Vol. 15 No. 4, pp. 485-505, doi: 10.1515/gej2015-0011.

Nasrullah, M., Chang, L., Khan, K., Rizwanullah, M., Zulfiqar, F. and Ishfaq, M. (2020), "Determinants of forest product group trade by gravity model approach: a case study of China”, Forest Policy and Economics, Vol. 113, 102117, doi: 10.1016/j.forpol.2020.102117.

Nguyen, B.X. (2010), “The determinants of Vietnamese export flows: static and dynamic panel gravity approaches”, International Journal of Economics and Finance, Vol. 2 No. 4, pp. 122-129, doi: 10. 5539/ijef.v2n4p122.

Nguyen, T.H. (2017), An Overview of Agricultural Pollution in Vietnam: The Crops Sector, World Bank, available at: https://openknowledge.worldbank.org/handle/10986/29241 (accessed 16 April 2020).

Nguyen, T.T.T. (2018), “The effect of Sanitary and phytosanitary measures on Vietnam's rice exports”, EconomiA, Vol. 19 No. 2, pp. 251-265, doi: 10.1016/j.econ.2017.12.001.

Nguyen, T.D. (2018), “Do trade agreements increase Vietnam's exports to RCEP markets?”, AsianPacific Economic Literature, Vol. 32 No. 1, pp. 94-107, doi: 10.1111/apel.12213.

Nguyen, K.D. and Heo, Y. (2009), "AFTA and Trade diversion: an empirical study for Vietnam and Singapore”, International area review, Vol. 12, pp. 163-192, doi: 10.1177/223386590901200109.

Nguyen, H.T.M., Do, H., Kay, A., Kompas, T., Nguyen, C.N. and Tran, C.T. (2017), “The political economy of policy exceptionalism during economic transition: the case of rice policy in Vietnam”, Crawford School Working Paper 1713, Crawford School of Public Policy, The Australian National University, available at: https://crawford.anu.edu.au/publication/crawfordschool-working-papers/12021/political-economy-policy-exceptionalism-during (accesed 25 April 2020).

Silva, J.M.C.S. and Tenreyro, S. (2006), "The log of gravity", The Review of Economics and Statistics, Vol. 88 No. 4, pp. 641-658, available at: https://www.mitpressjournals.org/doi/pdf/10.1162/rest. 88.4.641 (accessed 27 March 2020).

Tran, L.H. (2017), "Determinants of Vietnamese product export to Asean members", Journal of Economics and Development, Vol. 19 No. 3, pp. 91-110.

Tran, T.V.H., Nguyen, T.T.H., Tran, M.D., Hoang, V.H. and Hoang, V.H. (2019), "Impact of trade agreement on rice export: the case of Vietnam”, Uncertain Supply Chain Management, Vol. 7, pp. 727-740, doi: 10.5267/j.uscm.2019.2.001.

UN Comtrade (2020), UN Comtrade Database, UN Comtrade, available at: https:/comtrade.un.org/ data/ (accessed 2 March 2020).

UNDP (2016), Vietnam Drought and Saltwater Intrusion: Transitioning from Emergency to Recovery, UNDP, available at: https://reliefweb.int/sites/reliefweb.int/files/resources/Recovery $\% 20 \mathrm{draft} \%$ 20Sep\%202016_final\%20(2).pdf (accessed 16 April 2020).

$\mathrm{Vu}$, H.T. and Doan, H.Q. (2013), "Vietnamese rice exports: do large destination markets stimulate", MPRA Working Paper, No. 63891, available at: https://mpra.ub.uni-muenchen.de/63891/ (accessed 22 March 2020).

Wei, W. (2016), Achieving Inclusive Growth in China through Vertical Specialization, Chandos publishing, Elsevier, Kingston upon Hull.

Westerlund, J. and Wilhelmsson, F. (2011), "Estimating the gravity model without gravity using panel data”, Applied Economics, Vol. 43 No. 6, pp. 641-649, doi: 10.1080/00036840802599784.

\section{Further reading}

CEPII (2020), CEPII Database, CEPII, available at: http://www.cepii.fr/cepii/en/bdd_modele/bdd.asp (accessed 02 April 2020).
Vietnam's rice and coffee exports

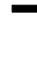


JABES

29,1

34
OECD (2020), OECD Statistics, OECD, available at: https://stats.oecd.org/viewhtml.aspx? datasetcode $=$ SNA_TABLE4\&lang $=$ en\# $($ accessed 1 April 2020).

World Bank (2020), World Development Indicator, The World Bank group, available at: https:// databank.worldbank.org/source/world-development-indicators\# (accessed 21 March 2020).

\section{Corresponding author}

Dao Dinh Nguyen can be contacted at: daond92@gmail.com

For instructions on how to order reprints of this article, please visit our website: www.emeraldgrouppublishing.com/licensing/reprints.htm Or contact us for further details: permissions@emeraldinsight.com 